\title{
Analisis kebijakan penempatan ahli gizi sebagai tenaga keolahragaan Indonesia
}

\author{
Mirza Hapsari Sakti Titis Penggalih ${ }^{1 *}$, Laksono Trisnantoro ${ }^{2}$, Zaenal Muttaqqien Sofro ${ }^{3}$, \\ Mutiara Tirta Prabandari Lintang Kusuma ${ }^{1}$, Mustika Cahya Nirmala Dewinta ${ }^{4}$, Ibtidau \\ Niamilah $^{1}$, Meta Anastasia ${ }^{4}$, Edi Nurinda Susila ${ }^{5}$
}

${ }^{1}$ Departemen Gizi Kesehatan, Fakultas Kedokteran, Kesehatan Masyarakat, dan Keperawatan, Universitas Gadjah Mada

${ }^{2}$ Departemen Ilmu Kesehatan Masyarakat, Fakultas Kedokteran, Kesehatan Masyarakat, dan Keperawatan, Universitas Gadjah Mada

${ }^{3}$ Departemen Ilmu Fisiologi, Fakultas Kedokteran, Kesehatan Masyarakat, dan Keperawatan, Universitas Gadjah Mada

${ }^{4}$ Magister Ilmu Kesehatan Masyarakat, Minat Gizi Kesehatan, Fakultas Kedokteran, Kesehatan Masyarakat, dan Keperawatan, Universitas Gadjah Mada,

Jl. Farmako, Sekip Utara, Yogyakarta 55281, Indonesia

${ }^{5}$ Pusat Pengembangan Ilmu Pengetahuan dan Teknologi Kesehatan Olahraga Nasional, Kemenpora Republik Indonesia, Jl. Gerbang Pemuda No.3, RT.1/RW.3, Gelora, Kecamatan Tanah Abang, Kota Jakarta Pusat, Daerah Khusus Ibukota Jakarta 10270, Indonesia

* Corresponding Author. Email: mirza.hapsari@ugm.ac.id

\begin{abstract}
Abstrak: Peran ahli gizi sebagai tenaga keolahragaan pada dasarnya merupakan mandat hukum dari UndangUndang No. 3 Tahun 2005 tentang Sistem Keolahragaan Nasional, khususnya Pasal 63 yang menyebutkan bahwa ahli gizi merupakan salah satu tenaga keolahragaan. Pada praktiknya, implementasi peran ahli gizi sebagai tenaga keolahragaan di pusat pembinaan atlet masih belum optimal. Keterbatasan sumber daya manusia dan anggaran, serta belum adanya kebijakan operasional yang mengatur tentang penempatan ahli gizi di pusat pembinaan atlet menjadi beberapa kendala yang perlu solusi. Pengkajian dilakukan dengan pendekatan kualitatif melalui studi dokumen terhadap delapan peraturan yaitu 1 undang-undang, 1 perpres dan 6 permen. Seluruh dokumen kebijakan tersebut selanjutnya ditetapkan pasal-pasal kritis yang dianalisis lebih lanjut untuk diberikan diskripsi penjelas, analisis mendalam pasal demi pasal, perumusan rekomendasi dan output kebijakan. Pengkajian telah mendapatkan Ethical Clearance Komisi Etik FKKMK UGM nomor: KE/FK/0292/EC/2020 pada tanggal 10 Maret 2020. Kajian terhadap Undang - Undang Nomor 3 Tahun 2005 dan peraturan hukum pendukungnya menunjukkan bahwa peran ahli gizi memiliki urgensi tinggi dalam pembinaan atlet. Namun demikian masih perlu kebijakan operasional yang mengatur tentang penempatan ahli gizi sebagai tenaga keolahragaan, meliputi tugas dan wewenang, serta standar kompetensi dan sertifikasi ahli gizi sebagai tenaga keolahragaan.
\end{abstract}

Kata Kunci: Ahli Gizi; Kebijakan; Tenaga Keolahragaan; Ahli Gizi Olahraga

\section{Policy analysis for the placement of nutritionists as Indonesian sports workers}

Abstract: The role of a nutritionist as a sports worker was basically a legal mandate from Law No. 3 of 2005 concerning the National Sports System, in particular Article 63, which stated that nutritionists were one of the sports personnel. In practice, the implementation of the nutritionist's role as a sports worker in the athlete training center was still minor. Limited human resources and budget, the absence of operational policies governing the placement of nutritionists in athlete training centers were some of the obstacles that hadn't had the solutions. This study used a qualitative approach by conducting document studies of eight regulations, all of which were 1 Law, 1 Presidential regulation and 6 Ministry regulations. All these policy documents were then defined as critical articles and further analyzed to provide explanatory descriptions, 


\section{Jurnal Keolahragaan 9 (2), 2021 - 179}

Mirza Hapsari Sakti Titis Penggalih, Laksono Trisnantoro, Zaenal Muttaqqien Sofro, Mutiara Tirta Prabandari

Lintang Kusuma, Mustika Cahya Nirmala Dewinta, Ibtidau Niamilah, Meta Anastasia, Edi Nurinda Susila

in-depth analysis of articles, formulation of recommendations and policy outputs. This study has obtained an Ethical Clearance from the Ethical Commission of the FKKMK UGM with number: KE / FK / 0292 / EC / 2020 on March 10, 2020. A study of Law Number 3 of 2005 and its supporting legal regulations showed that the role of nutritionists was urgently entailed in athlete coaching. However, an operational policy regulating the sports nutrition personnel placement is still required. It includes their duties and authority, competency standards and certification of nutritionists as sports personnel.

Keywords: Nutritionist; Policy; Sports Worker, Sport nutritionist

How to Cite: Penggalih, M.H.S.T., Trisnantoro, L., Sofro, Z.M., Kusuma, M.T.P.L., Dewinta, M.C.N., Niamilah, I., Anastasia, M., \& Susila, E.N,. (2021). Analisis Kebijakan Penempatan Ahli Gizi Sebagai Tenaga Keolahragaan Indonesia. Jurnal Keolahragaan, 9(2), 178-192. doi: https://doi.org/10.21831/jk.v9i2.38193

\section{PENDAHULUAN}

Tubuh yang mendapatkan zat gizi cukup merupakan kunci untuk memperoleh status gizi optimal. Zat gizi tersebut kemudian digunakan untuk pertumbuhan, perkembangan otak, serta aktivitas fisik (Sepriadi, 2017). Penelitian menunjukkan bahwa atlet memiliki risiko untuk mengalami ketidakseimbangan asupan gizi, baik pada kelompok atlet pelajar (Kim, Oh, \& Lee, 2019) hingga atlet professional (Ong \& Brownlee, 2017). Ketidak seimbangan pemenuhan gizi pada atlet terjadi baik pada zat gizi makro maupun zat gizi mikro. Kebutuhan atlet sangat bergantung dengan cabang olahraga yang digeluti. Atlet remaja memiliki berbagai macam kebutuhan gizi berdasarkan ukuran tubuh, intensitas latihan, usia, dan jenis kelamin (Berg, 2019). Selain itu, kebutuhan gizi atlet sangat bervariasi tergantung posisi dalam suatu tim, musim yang sedang dihadapi, sesi latihan dan sesi istirahat. Tujuan yang akan dicapai seorang atlet dalam periode tertentu juga menjadi salah satu pertimbangan mementukan kebutuhan gizi. Sebagai contoh atlet akan merencanakan untuk memiliki massa otot tanpa lemak, menurunkan kadar lemak tubuh, atau mempertahankan komposisi tubuh mereka saat ini tanpa menghambat performa di lapangan (Bytomski, 2018).

Berbagai studi pada atlet di Indonesia juga mengungkapkan terjadinya asupan zat gizi yang tidak seimbang, seperti yang ditemukan pada atlet pelajar di berbagai pusat pembinaan atlet (Penggalih et al., 2016; Penggalih et al., 2019). Kajian yang dilakukan oleh (Tahir et al, 2019) di PPLP Provinsi Sulawesi Selatan menyatakan bahwa kecukupan energi tergolong sangat kurang, karbohidrat dan protein tergolong kurang, serta lemak tergolong normal. Fenomena ketidakseimbangan asupan zat gizi pada atlet tersebut dipengaruhi oleh beberapa faktor, seperti kurangnya edukasi tentang urgensi gizi terhadap performa olahraga, pengetahuan terkait gizi dan olahraga, serta lemahnya sistem pengaturan gizi pada suatu tim olahraga atau pusat latihan atlet (Jenner et al., 2018).

Pemenuhan kebutuhan energi dan zat gizi pada atlet memiliki urgensi yang tinggi, karena menentukan kualitas kesehatan atlet serta pencapaian performa olahraga (Ong \& Brownlee, 2017). Penelitian pada atlet sepakbola remaja mengungkapkan bahwa intervensi gizi komprehensif membantu menunjang performa atlet sebesar 69,8\% (Penggalih et al, 2017). Selain itu fokus gizi pada atlet elit remaja salah satunya bertujuan untuk memperbaiki pola makan yang mana hal ini merupakan pertimbangan dalam pencegahan cedera atau penyakit (von Rosen et al, 2017). Atlet cabang olahraga dengan risiko cedera tinggi diantaranya atlet angkat besi, atlet angkat berat dan atlet tinju (Baihaqi, 2021). Diperlukan pendampingan ahli gizi untuk meminimalkan kondisi cedera pada atlet. Relevan dengan urgensi tersebut, Academy of Nutrition and Dietetic (Academy), Dietitians of Canada (DC), dan American College of Sports Medicine (ACSM) memberikan panduan bahwa dalam sebuah sistem pembinaan dan latihan, atlet perlu mendapatkan edukasi, konseling, dan preskripsi diet dari ahli gizi sehingga kebutuhan zat gizi dapat terpenuhi (Thomas et al, 2016).

Peran ahli gizi sebagai tenaga keolahragaan pada dasarnya merupakan mandat hukum dari Undang-Undang No. 3 Tahun 2005 tentang Sistem Keolahragaan Nasional, khususnya Pasal 63 yang menyebutkan bahwa ahli gizi merupakan salah satu tenaga keolahragaan. Selain itu, dalam Peraturan Presiden No. 95 Tahun 2017 tentang Peningkatan Prestasi Olahraga Nasional, Pasal 13 Ayat 1 menjelaskan tentang pelatihan performa tinggi melalui penyiapan fisik atlet berprestasi dan program latihan kekuatan serta pengkondisian (strength and conditioning). Pengetahuan, asupan, dan pencapaian 


\section{Jurnal Keolahragaan 9 (2), 2021 - 180}

Mirza Hapsari Sakti Titis Penggalih, Laksono Trisnantoro, Zaenal Muttaqqien Sofro, Mutiara Tirta Prabandari

Lintang Kusuma, Mustika Cahya Nirmala Dewinta, Ibtidau Niamilah, Meta Anastasia, Edi Nurinda Susila

status gizi yang memadai dan optimal merupakan aspek yang harus dipenuhi dalam fase pengkondisian tersebut. Lebih lanjut, Peraturan Menteri Pemuda dan Olahraga No. 2 Tahun 2017 Pasal 4 Ayat 3 menyebutkan bahwa ilmu gizi olahraga (sport nutrition) adalah salah satu cabang ilmu terapan dalam Ilmu Pengetahuan dan Teknologi (IPTEK) Keolahragaan yang perlu dikembangkan. Sehingga diperlukan peran ahli gizi dalam penatalaksanaan gizi atlet sebagai bentuk penerapan IPTEK Keolahragaan tersebut.

Pada praktiknya, implementasi peran ahli gizi sebagai tenaga keolahragaan di pusat pembinaan atlet masih belum optimal. Keterbatasan sumber daya manusia, anggaran, serta ketidaktersediaan kebijakan operasional yang mengatur tentang penempatan ahli gizi di pusat pembinaan atlet menjadi beberapa kendala yang memerlukan solusi. Adanya kesenjangan dalam implementasi kebijakan tersebut mengundang adanya upaya perbaikan kebijakan terkait sistem penyelenggaraan gizi pada atlet. Kebijakan operasional tentang penempatan ahli gizi sebagai tenaga keolahragaan di berbagai sekolah olahraga dan pusat pembinaan atlet perlu dirumuskan sebagai bentuk penafsiran kebijakan UndangUndang Nomor 3 Tahun 2005 Pasal 63 tentang Tenaga Keolahragaan. Sesuai teori siklus pembuatan kebijakan publik (Blomkamp et al, 2017), tahap pertama yang harus dilalui dalam merumuskan kebijakan adalah pembentukan agenda setting dan identifikasi masalah sesuai konteks terkait.

Berdasarkan latar belakang tersebut, pengkajian ini dilakukan untuk menganalisis implementasi kebijakan Undang-Undang Nomor 3 Tahun 2005 Pasal 63 yang telah dilakukan, sebagai upaya untuk mengidentifikasi potensi hambatan dan peluang yang akan dihadapi dalam rencana penempatan ahli gizi di berbagai sekolah olahraga dan pusat pembinaan atlet.

\section{METODE}

Metode penelitian ini adalah kualitatif dengan pendekatan studi dokumen dengan mengumpulkan dokumen-dokumen kebijakan yang relevan dengan sistem penjaminan kesehatan dan penyelenggaraan gizi pada atlet di Indonesia. Terdapat 8 peraturan atau kebijakan yang dikupas dalam penelitian ini, yaitu (1) Undang-Undang No. 3 Tahun 2005 tentang Sistem Keolahragaan Nasional, (2) Peraturan Pemerintah No. 16 Tahun 2007 tentang Penyelenggaraan Keolahragaan, (3) Peraturan Menteri Kesehatan No. 26 Tahun 2013 tentang Penyelenggaraan Pekerjaan dan Praktik Tenaga Gizi, (4) Peraturan Menteri Pemuda dan Olahraga No. 1684 Tahun 2015 tentang Persyaratan Pemberian Penghargaan Olahraga kepada Olahragawan, Pembina olahraga, Tenaga Keolahragaan, dan Organisasi Keolahragaan, (5) Peraturan Menteri Pemuda dan Olahraga No. 2 Tahun 2017 tentang Tata Cara Pengembangan Ilmu Pengetahuan dan Teknologi Keolahragaan, (6) Peraturan Presiden No. 95 Tahun 2017 tentang Peningkatan Prestasi Olahraga Nasional, (7) Peraturan Menteri Pemuda dan Olahraga No. 24 Tahun 2017 tentang Kriteria dan Standar Pengembangan Bakat Calon Atlet Berprestasi Serta Pemberian Penghasilan dan Fasilitas Kepada Atlet dan Pelatih Atlet Berprestasi, dan (8) Peraturan Menteri Pemuda dan Olahraga No. 5 Tahun 2020 tentang Pelimpahan Sebagian Urusan Pemerintahan Bidang Kepemudaan dan Keolahragaan Kepada Gubernur Sebagai Wakil Pemerintah Pusat Dalam Rangka Penyelenggaraan Dekonsentrasi. Selanjutnya, ditetapkan pasal-pasal kritis yang akan dianalisis lebih lanjut dan mendalam, serta diberikan rumusan rekomendasi dan output kebijakan.

Penelitian ini adalah rangkaian kegiatan riset yang berjudul "Studi Implementasi Kebijakan Peran Ahli Gizi di Lingkungan Kementerian Pemuda dan Olahraga Republik Indonesia dalam rangka Menunjang Prestasi Atlet Nasional" yang telah memperoleh Ethical Clearance dari Komisi Etik FKKMK UGM dengan nomor: KE/FK/0292/EC/2020 pada tanggal 10 Maret 2020.

\section{HASIL DAN PEMBAHASAN}

\section{Hasil}

Implementasi kebijakan penempatan ahli gizi di lingkungan Kemenpora RI perlu diawali dengan kajian terhadap peraturan-peraturan hukum terkait penyelenggaraan keolahragaan nasional, sehingga sistem nasional saat ini dapat dipahami lebih dalam. Analisis kebijakan dilakukan melalui pendekatan penilaian efektivitas implementasi peraturan dan kesesuaian manfaat dari suatu peraturan dengan yang diharapkan. Terdapat 8 peraturan hukum yang ditelaah dalam penulisan ini meliputi 1 peraturan Perundang-undangan, 1 Peraturan presiden dan 6 Peraturan Menteri. penjelasan rinci setiap pasal yang berhubungan dengan penempatan ahli gizi disajikan dalam Tabel 1. 


\section{Jurnal Keolahragaan 9 (2), 2021 - 181}

Mirza Hapsari Sakti Titis Penggalih, Laksono Trisnantoro, Zaenal Muttaqqien Sofro, Mutiara Tirta Prabandari Lintang Kusuma, Mustika Cahya Nirmala Dewinta, Ibtidau Niamilah, Meta Anastasia, Edi Nurinda Susila

Tabel 1. Analisis Peraturan Hukum terkait Tenaga Keolahragaan

$\begin{array}{lcc}\text { No. Judul Peraturan } & \text { Pasal-pasal } & \text { Kritis }\end{array}$

1. Undang-Undang No. $3 \quad$ Pasal 63

Tahun 2005 tentang

Sistem Keolahragaan

Nasional

2. Peraturan Pemerintah

No. 16

Tahun 2007 tentang

Penyelenggaraan

Keolahragaan
Pasal 14

(1) Ahli gizi termasuk sebagai tenaga keolahragaan yang terlibat dalam penyelenggaraan olahraga di Indonesia.

(2) Dalam menjalankan tugas sesuai keahliannya, tenaga keolahragaan wajib memperoleh sertifikat kompetensi dari instansi pemerintah yang berwenang.

(3) Kegiatan pelatihan perlu dilakukan dalam proses pengadaan tenaga keolahragaan.

Kegiatan olahraga nasional merupakan tanggungjawab pemerintah, baik pusat maupun daerah.

Pasal 16

Pasal 75

Pasal 76

Pasal 84

Pasal 85

Pasal 87
Pemerintah Daerah memiliki tanggungjawab dalam pelaksanaan kegiatan olahraga nasional, yaitu melaksanaka kebijakan olahraga nasional secara operasional di daerah masing-masing sesuai dengan kewenangan yang diatur dalam Perundang-undangan. Pengembangan IPTEK Keolahragaan di Indonesia dilakukan melalui perencanaan sistematis yang meliputi kegiatan penelitian, uji coba, diseminasi hasil penelitian, pemanfaatan hasil penelitian, hingga evaluasi dan pengembangan secara berkelanjutan.

(1) Pemerintah, baik pusat maupun daerah, memiliki tanggungjawab untuk memfasilitasi pemberdayaan sumber daya manusia serta peningkatan sarana prasarana pendukung kegiatan pengembangan IPTEK keolahragaan.

(2) Fasilitasi yang dapat dilakukan pemerintah berupa pendanaan, bantuan teknis, kemudahan pelayanan, serta penyediaan akses informasi. Standarisasi Nasional Keolahragaan diperlukan untuk menjamin kualitas penyelenggaraan sistem keolahragaan nasional.

Ruang lingkup yang diatur dalam standar nasional keolahragaan antara lain kompetensi tenaga keolahragaan, program pelatihan tenaga keolahragaan, sarana prasarana olahraga, pengelolaan organisasi olahraga, kegiatan olahraga, hingga pelayanan minimal keolahragaan.

(1) Persyaratan yang harus dipenuhi tenaga keolahragaan untuk memperoleh sertifikat kompetensi mencakup ruang lingkup:
a. Riwayat pendidikan formal,
b. Riwayat pelatihan berakreditasi,
c. Pengalaman kerja dan penghargaan,
d. Hasil uji kompetensi,
e. Kesehatan fisik dan mental

(2) Kompetensi yang harus dipenuhi tenaga keolahragaan meliputi kmpetensi akademik, kepribadian, profesional, dan sosial. 
Jurnal Keolahragaan 9 (2), 2021 - 182

Mirza Hapsari Sakti Titis Penggalih, Laksono Trisnantoro, Zaenal Muttaqqien Sofro, Mutiara Tirta Prabandari Lintang Kusuma, Mustika Cahya Nirmala Dewinta, Ibtidau Niamilah, Meta Anastasia, Edi Nurinda Susila

\begin{tabular}{|c|c|c|c|}
\hline No. & Judul Peraturan & $\begin{array}{c}\text { Pasal-pasal } \\
\text { Kritis }\end{array}$ & Konten Pasal \\
\hline 3. & $\begin{array}{l}\text { Peraturan Menteri } \\
\text { Kesehatan No. } 26 \\
\text { Tahun } 2013 \text { tentang } \\
\text { Penyelenggaraan } \\
\text { Pekerjaan dan Praktik } \\
\text { Tenaga Gizi }\end{array}$ & $\begin{array}{l}\text { Pasal } 92 \\
\text { Ayat (1) dan } \\
\text { Ayat (4) }\end{array}$ & $\begin{array}{l}\text { (1) Tenaga keolahragaan merupakan salah satu } \\
\text { ruang lingkup yang diatur dalam Standar } \\
\text { Pelayanan Minimal Keolahragaan. } \\
\text { (4) Setiap tenaga keolahragaan yang terlibat dalam } \\
\text { kegiatan olahraga wajib memiliki kualifikasi dan } \\
\text { kompetensi di bidang keolahragaan. } \\
\text { (1) Selain di puskesmas, klinik, dan rumah sakit, } \\
\text { tenaga Gizi yang mempunyai SIKTGz } \\
\text { dapat melakukan praktik di fasilitas kesehatan } \\
\text { lainnya. } \\
\text { (2) Praktik asuhan gizi secara mandiri dapat dilakukan } \\
\text { oleh ahli gizi yang telah memiliki SIPTGz. }\end{array}$ \\
\hline 4. & $\begin{array}{l}\text { Peraturan Menteri } \\
\text { Pemuda dan Olahraga } \\
\text { No. } 1684 \text { Tahun } 2015 \\
\text { tentang Persyaratan } \\
\text { Pemberian Penghargaan } \\
\text { Olahraga kepada } \\
\text { Olahragawan, Pembina } \\
\text { olahraga, Tenaga } \\
\text { Keolahragaan, dan } \\
\text { Organisasi } \\
\text { Keolahragaan }\end{array}$ & Pasal 17 & $\begin{array}{l}\text { Kewenangan yang dimiliki oleh ahli gizi di fasilitas } \\
\text { pelayanan kesehatan antara lain: } \\
\text { a. Konseling dan edukasi gizi } \\
\text { b. Pengkajian, diagnosis, dan intervensi gizi } \\
\text { c. Pelatihan dan penelitian } \\
\text { d. Penyelenggaraan makanan massal } \\
\text { Ahli gizi termasuk sebagai salah satu tenaga } \\
\text { keolahragaan yang telah diatur standar pemberian } \\
\text { penghargaannya apabila mencapai prestasi tertentu } \\
\text { yang dibuktikan dengan sertifikat atau bukti } \\
\text { penghargaan lain. }\end{array}$ \\
\hline 5 & $\begin{array}{l}\text { Peraturan Menteri } \\
\text { Pemuda dan Olahraga } \\
\text { No. } 2 \text { Tahun } 2017 \\
\text { tentang Tata Cara } \\
\text { Pengembangan Ilmu } \\
\text { Pengetahuan dan } \\
\text { Teknologi } \\
\text { Keolahragaan }\end{array}$ & Pasal 4 & $\begin{array}{l}\text { (1) IPTEK Keolahragaan yang perlu dikembangkan } \\
\text { meliputi ilmu dasar (basic science) dan ilmu } \\
\text { terapan (applied science). } \\
\text { (2) Ilmu gizi olahraga (sport nutrition) merupakan } \\
\text { salah satu cabang ilmu terapan yang perlu } \\
\text { dikembangkan. }\end{array}$ \\
\hline 6 & $\begin{array}{l}\text { Peraturan Presiden No. } \\
95 \\
\text { Tahun } 2017 \text { tentang } \\
\text { Peningkatan Prestasi } \\
\text { Olahraga Nasional }\end{array}$ & Pasal 4 & $\begin{array}{l}\text { Program pengembangan bakat calon atlet berprestasi } \\
\text { dilakukan terhadap olahragawan yang berpotensi } \\
\text { mencapai prestasi puncak. Program dilakukan dengan } \\
\text { prinsip pembinaan berjenjang dalam jangka waktu } \\
\text { panjang. }\end{array}$ \\
\hline & & Pasal 5 & $\begin{array}{l}\text { (1) KONI beserta induk organisasi cabang olahraga } \\
\text { bertugas dalam melakukan program } \\
\text { pengembangan bakat calon atlet berprestasi. }\end{array}$ \\
\hline & & Pasal 6 & 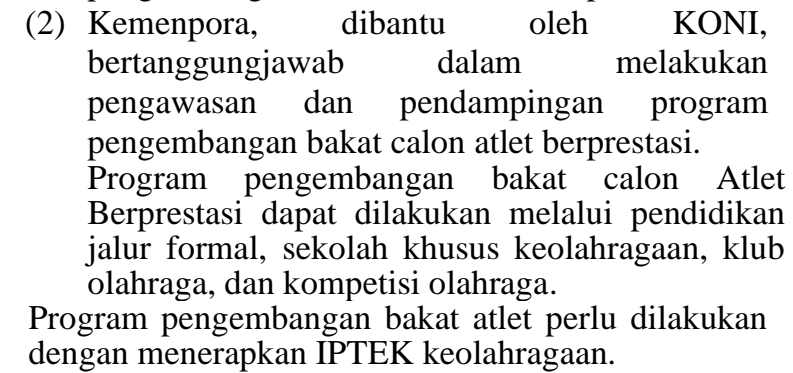 \\
\hline
\end{tabular}


Jurnal Keolahragaan 9 (2), 2021 - 183

Mirza Hapsari Sakti Titis Penggalih, Laksono Trisnantoro, Zaenal Muttaqqien Sofro, Mutiara Tirta Prabandari Lintang Kusuma, Mustika Cahya Nirmala Dewinta, Ibtidau Niamilah, Meta Anastasia, Edi Nurinda Susila

\begin{tabular}{lll} 
No. Judul Peraturan & $\begin{array}{c}\text { Pasal-pasal } \\
\text { Kritis }\end{array}$ & \multicolumn{1}{c}{ Konten Pasal } \\
\hline & Pasal 7 & $\begin{array}{l}\text { Program pengembangan bakat atlet harus memenuhi } \\
\text { kriteria standar yang diatur lebih lanjut melalui } \\
\text { Peraturan Menteri. }\end{array}$
\end{tabular}

Pasal 12 Dalam rangka menghasilkan atlet berprestasi yang diharapkan, program latihan performa tinggi (high performance training) yang dilakukan oleh NPC dan induk organisasi cabang olahraga harus menerapkan minimal prinsip adaptasi dan individualisasi, peningkatan beban latihan bertahap, serta spesifikasi

Pasal 13 jenis latihan.

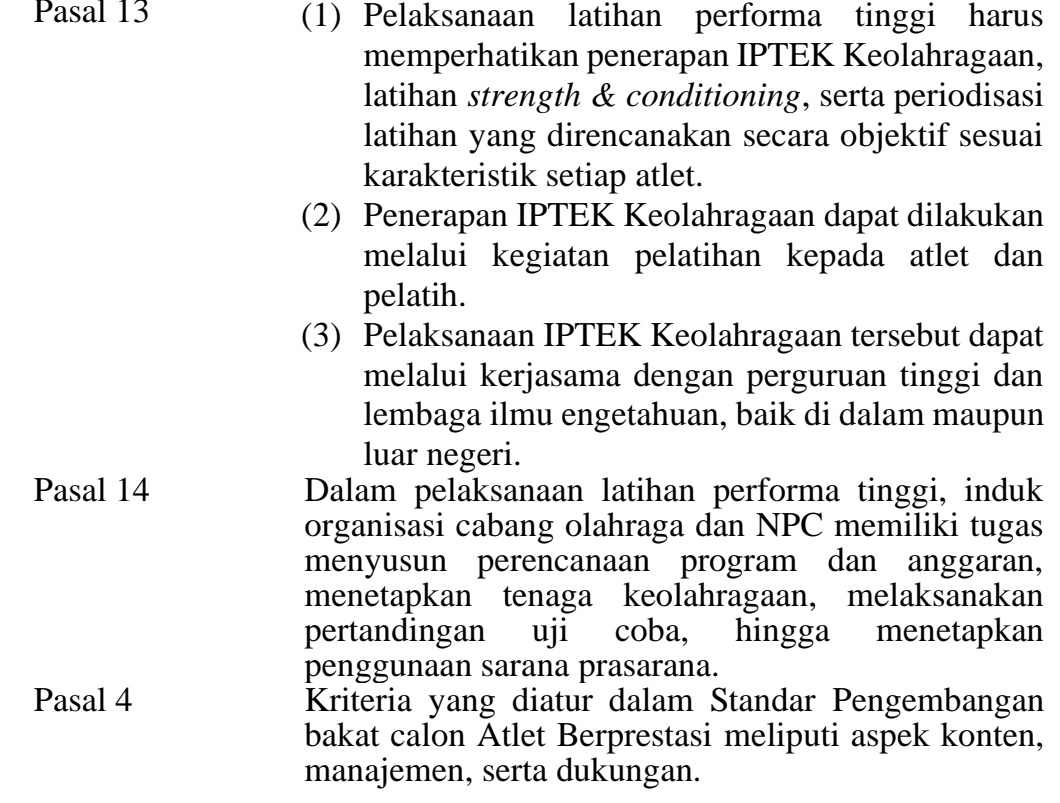

7 Peraturan Menteri Pemuda dan Olahraga No. 24 Tahun 2017 tentang Kriteria dan Standar Pengembangan Bakat Calon Atlet Berprestasi Serta Pemberian Penghasilan dan Fasilitas Kepada Atlet dan Pelatih Atlet Berprestasi
Pasal 5

Pasal 11

Pasal 12

Pasal 13
Konten yang diatur meliputi tenaga keolahragaan, IPTEK keolahragaan, sarana prasarana olahraga, dan kegiatan kejuaraan.

Program pengembangan bakat atlet dapat dilaksanakan melalui berbagai bentuk pendidikan baik jalur formal, sekolah khusus olahragawan, klub olahraga, hingga kejuaraan olahraga.

Pendidikan olahraga melalui jalur formal di sekolah dapat diselenggarakan dengan kegiatan ekstrakurikuler olahraga, kelas khusus olahraga, dan klub olahraga di sekolah.

Pengembangan bakat atlet yang dilakukan di sekolah khusus olahraga dilakukan dengan prinsip pembinaan berjenjang dan berkelanjutan yang berpedoman pada kurikulum khusus olahraga. 
Mirza Hapsari Sakti Titis Penggalih, Laksono Trisnantoro, Zaenal Muttaqqien Sofro, Mutiara Tirta Prabandari Lintang Kusuma, Mustika Cahya Nirmala Dewinta, Ibtidau Niamilah, Meta Anastasia, Edi Nurinda Susila

\begin{tabular}{|c|c|c|c|}
\hline No. & Judul Peraturan & $\begin{array}{c}\text { Pasal-pasal } \\
\text { Kritis }\end{array}$ & Konten Pasal \\
\hline 8 & $\begin{array}{l}\text { Peraturan Menteri } \\
\text { Pemuda dan Olahraga } \\
\text { No. } 5 \text { Tahun } 2020 \\
\text { tentang Pelimpahan } \\
\text { Sebagian Urusan } \\
\text { Pemerintahan Bidang } \\
\text { Kepemudaan dan } \\
\text { Keolahragaan Kepada } \\
\text { Gubernur Sebagai } \\
\text { Wakil Pemerintah Pusat } \\
\text { Dalam Rangka } \\
\text { Penyelenggaraan } \\
\text { Dekonsentrasi }\end{array}$ & $\begin{array}{l}\text { Pasal } 17 \\
\text { ayat (1) dan } \\
\text { ayat (3) }\end{array}$ & $\begin{array}{l}\text { Selama program pelatihan nasional, atlet dan pelatih } \\
\text { berprestasi memperoleh pembinaan kehidupan sosial } \\
\text { meliputi pemberian penghasilan dan fasilitas serta } \\
\text { penghargaan olahraga. } \\
\text { (1) Pemberian penghasilan dan fasilitas yang diterima } \\
\text { selama program latihan nasional meliputi } \\
\text { honorarium bulanan, akomodasi dan konsumsi, } \\
\text { suplemen, biaya perjalanan, serta pemeriksaan } \\
\text { kesehatan. } \\
\text { (2) Pemberian fasilitas tersebut dilakukan dengan } \\
\text { mengoptimalkan layanan pada Rumah Sakit } \\
\text { Olahraga Nasional (RSON) } \\
\text { Pengembangan ilmu pengetahuan dan teknologi, } \\
\text { dan Kesehatan Olahraga Nasional (PPITKON). Tarif } \\
\text { yang diberikan adalah } 0 \text { (nol) rupiah yang mengacu } \\
\text { pada perudangan tentang penerimaan negara bukan } \\
\text { pajak di lingkungan Kemenpora RI. } \\
\text { Dalam kegiatan peningkatan prestasi olahraga } \\
\text { nasional, NPC dan induk organisasi cabang olahraga } \\
\text { memiliki tugas untuk melakukan program latihan } \\
\text { performa tinggi berbasis IPTEK keolahragaan serta } \\
\text { menetapkan tenaga keolahragaan. Ahli gizi } \\
\text { merupakan salah satu tenaga yang dilibatkan sebagai } \\
\text { tim pendukung. } \\
\text { Kegiatan yang dapat dikelola dengan Dana } \\
\text { Dekonsentrasi antara lain program peningkatan } \\
\text { wawasan pemuda, pengelolaan sentra dan SKO, serta } \\
\text { pengembangan tenaga dan organisasi keolahragaan. }\end{array}$ \\
\hline
\end{tabular}

\section{Pembahasan}

Rekomendasi dari studi yang dilaksanakan oleh (Sulistiyono, 2020) menyebutkan tentang perlunya pengadaan ahli gizi bagi atlet binaan di PPLP. Hal ini didasarkan pada hasil kajian yang dilaksanakan di PPLP Jawa Barat yaitu adanya kebijakan pengadaan gizi atlet PPLP yang tercantum dalam peraturan Dinas Pemuda dan Olahraga Jawa Barat, namun dalam hal ini belum disertai dengan pengadaan ahli gizi untuk mengatur gizi atlet. Tidak adanya ahli gizi dalam hal ini menyebabkan pengaturan gizi pada atlet PPLP Jawa Barat tidak dibedakan menurut cabang olahraga serta perhitungan kebutuhan gizi didasarkan pada kebutuhan menurut periodesasi pra kompetisi saja. Selain itu pengukuran status gizi atlet belum termonitor dengan baik karena tidak ada ahli gizi. Oleh karena itu diperlukan pengkajian terhadap undang-undang serta peraturan yang ada.

\section{Undang-Undang No. 3 Tahun 2005 tentang Sistem Keolahragaan Nasional (Pemerintah Republik Indonesia, 2005)}

Pada Pasal 63 ini disebutkan bahwa ahli gizi termasuk 1 dari 15 tenaga keolahragaan yang perlu dilibatkan dalam penyelenggaraan kegiatan olahraga, sehingga ahli gizi perlu memiliki kualifikasi dan sertifikat kompetensi dalam bidang olahraga. UU No. 3 Tahun 2005 Pasal 63 ini menjadi dasar hukum tertinggi tentang peran ahli gizi sebagai tenaga keolahragaan di Indonesia. Agar kebijakan tersebut dapat 


\section{Jurnal Keolahragaan 9 (2), 2021 - 185}

Mirza Hapsari Sakti Titis Penggalih, Laksono Trisnantoro, Zaenal Muttaqqien Sofro, Mutiara Tirta Prabandari

Lintang Kusuma, Mustika Cahya Nirmala Dewinta, Ibtidau Niamilah, Meta Anastasia, Edi Nurinda Susila

diimplementasikan dengan baik, maka diperlukan peraturan-peraturan hukum turunannya yang dapat menerjemahkan secara operasional tugas dan wewenang ahli gizi sebagai tenaga keolahragaan. Pembentukan regulasi yang lebih operasional tersebut bertujuan untuk memudahkan pelaksana kebijakan di lapangan (pengelola pusat latihan atlet) dalam mengadopsi kebijakan. Kebijakan yang tidak didukung oleh penjelasan operasional berpotensi menjadi hambatan dalam implementasinya (Health Policy Project, 2014). Sebaliknya, dengan adanya regulasi yang lebih operasional akan meningkatkan efektivitas dan efisiensi kerja dari pelaksana kebijakan di lapangan, sehingga luaran implementasi kebijakan dapat tercapai dengan baik (Jones, 2013).

\section{Peraturan Pemerintah No. 16 Tahun 2007 tentang Penyelenggaraan Keolahragaan (Pemerintah Republik Indonesia, 2007)}

Pasal 14 dan 16 dapat dijadikan dasar hukum perlunya keterlibatan pemerintah daerah dalam penyelenggaraan keolahragaan. Pasal 16 poin "e" menyebutkan pemerintah daerah memiliki tanggung jawab untuk menyediakan pelaksanaan kegiatan keolahragaan sesuai dengan standar pelayanan minimum. Lebih lanjut dijelaskan pada Pasal 92 bahwa salah satu persyaratan pelayanan minimum adalah tenaga keolahragaan yang mendukung kegiatan olahraga. Oleh karena itu, terkait pembinaan atlet di PPLP pada setiap provinsi, dibutuhkan keterlibatan pemerintah daerah dalam pemenuhan kebutuhan tenaga keolahragaan, termasuk ahli gizi.

Pasal ini lebih lanjut menyatakan bahwa pengembangan IPTEK Keolahragaan dilakukan secara terencana dan berkelanjutan mulai dari perencanaan, penelitian, uji coba, alih teknologi, diseminasi dan sosialisasi hasil, pemanfaatan hasil, hingga analisis dan evaluasi. Poin penting yang belum dipertimbangkan adalah bagaimana hasil pengembangan IPTEK tersebut kemudian dijadikan landasan dalam penyusunan kebijakan keolahragaan nasional. Poin (c) pada pasal tersebut tentang uji coba IPTEK Keolahragaan dapat menjadi dasar dalam penyelenggaraan pilot project atau uji coba ahli gizi untuk ditempatkan di PPLP/SKO di berbagai wilayah Indonesia. Oleh karena itu, komitmen dan dukungan Kementerian Pemuda dan Olahraga dalam kegiatan uji coba tersebut sangat diharapkan sebagai bentuk pelaksanaan mandat hukum pengembangan IPTEK Keolahragaan.

Pasal ini menyatakan fasilitasi penyelenggaraan dan pengembangan IPTEK Keolahragaan, berupa bantuan dana, teknis, kemudahan, pelayanan, dan penyediaan informasi merupakan kewajiban pemerintah pusat dan daerah. Hal ini dapat menjadi dasar hukum untuk pengajuan anggaran uji coba kebijakan penempatan ahli gizi di PPLP/SKO di beberapa wilayah Indonesia.

Dalam tatanan sistem keolahragaan nasional menyebutkan bahwa ahli gizi termasuk sebagai tenaga keolahragaan yang perlu dilibatkan pada penyelenggaraan olahraga. Dengan demikian, Pasal (8485) ini menjadi landasan diperlukannya standarisasi kompetensi dan program pelatihan ahli gizi sebagai tenaga keolahragaan, serta standarisasi pendampingan gizi atlet sebagai bagian dari pelayanan minimal keolahragaan.

Berkaitan dengan peran ahli gizi sebagai tenaga keolahragaan, standar kompetensi gizi olahraga perlu merujuk pada standar kompetensi ahli gizi yang diatur dalam Permenkes No. 26 Tahun 2013, sementara standar pendampingan gizi atlet merujuk pada standar pelayanan minimal kesehatan yang diatur dalam Permenkes No. 741 Tahun 2008. Peran badan standardisasi diperlukan untuk menghubungkan peraturan-peraturan tersebut agar kebijakan penempatan ahli gizi sebagai tenaga keolahragaan dapat diterapkan dengan tepat. Hal itu dapat dilakukan dengan merumuskan kembali kebijakan terkini tentang standarisasi ahli gizi sebagai tenaga keolahragaan. Oleh karena itu, perlu adanya koordinasi antar pemangku kepentingan (stakeholder) yang terlibat seperti Kementerian Kesehatan, Pusat Pendidikan Sumber Daya Manusia (PPSDM), PERSAGI, dan Badan Standarisasi Nasional (BSN) untuk membuat kesepakatan tentang standardisasi, akreditasi dan sertifikasi sehingga tercipta aturan spesifik untuk penempatan ahli gizi sebagai tenaga keolahragaan yang sesuai dengan standar kompetensi.

\section{Peraturan Menteri Kesehatan No. 26 Tahun 2013 tentang Penyelenggaraan Pekerjaan dan Praktik Tenaga Gizi (Kementerian kesehatan RI, 2013)}

Kepemilikan SITGz dan SIPGz merupakan syarat ahli gizi untuk melakukan pelayanan gizi di fasilitas pelayanan kesehatan secara mandiri. Namun belum dijelaskan salah satu fasilitas kesehatan adalah pusat pembinaan dan pelatihan atlet. Menurut UU SKN No 3/2005, pembinaan atlet 
Mirza Hapsari Sakti Titis Penggalih, Laksono Trisnantoro, Zaenal Muttaqqien Sofro, Mutiara Tirta Prabandari

Lintang Kusuma, Mustika Cahya Nirmala Dewinta, Ibtidau Niamilah, Meta Anastasia, Edi Nurinda Susila

membutuhkan ahli gizi sehingga kewenangan ahli gizi di bidang olahraga juga perlu diakui dan diatur oleh organisasi profesi ahli gizi.

Pasal ini juga menjelaskan standar kerja ahli gizi dalam melakukan pelayanan gizi di fasilitas pelayanan kesehatan. Sementara itu, dunia olahraga yang menjadi lingkup kerja ahli gizi olahraga memiliki beberapa perbedaan karakteristik dibandingkan fasilitas pelayanan kesehatan yang sudah diatur dalam Pasal ini. Selama ini pada praktiknya tugas ahli gizi pada atlet hanya dipahami sebatas menyusun menu dan menyelenggarakan pengadaan makanan untuk atlet. Sementara itu, melakukan pengukuran status gizi yang spesifik berkaitan dengan komposisi tubuh dan somaotipe atlet, mendampingi kebutuhan gizi pada setiap periodisasi latihan, memberikan edukasi gizi kepada atlet, pelatih, hingga tim manajemen atlet, hingga mengatur pengadaan makan food service sesuai standar kebutuhan gizi atlet juga merupakan tugas ahli gizi olahraga . Apabila ruang lingkup praktik ahli gizi di pusat pelatihan atlet sudah ditambahkan pada Pasal 14 Ayat (1), maka kewenangan ahli gizi yang spesifik di bidang olahraga dapat terfasilitasi di Pasal 17 ini.

Peraturan Menteri Pemuda dan Olahraga No. 1684 Tahun 2015 tentang Persyaratan Pemberian Penghargaan Olahraga kepada Olahragawan, Pembina olahraga, Tenaga Keolahragaan, dan Organisasi Keolahragaan (Kementerian Pemuda dan Olahraga RI, 2015)

Pasal 1 terutama Ayat (4), (7), dan (10) tentang pelaku-pelaku olahraga yang salah satunya adalah ahli gizi. Pasal ini menegaskan bahwa peran ahli gizi sebagai tenaga keolahragaan memiliki legalitas hukum yang jelas, serta telah diatur standar pemberian penghargaannya apabila mencapai prestasi tertentu sebagai tenaga keolahragaan. Ahli gizi selaku pelaku olahraga ini memiliki kewajiban mengupayakan pemberian pelayanan gizi sebagai salah satu strategi pembinaan olahraga. Dengan demikian, atlet dapat mencukupi kebutuhan gizi yang ideal melalui bimbingan ahli gizi sehingga membantu mencapai prestasi olahraga.

Apabila telah terdapat regulasi yang mengatur tentang penghargaan kepada ahli gizi sebagai tenaga keolahragaan, maka dibutuhkan penjelasan regulasi yang lebih operasional tentang indikator kerja ahli gizi olahraga yang perlu dicapai. Tugas ahli gizi sebagai tenaga keolahragaan dapat mengacu pada hasil konsensus dari Academy, DC, dan ACSM. Tugas ahli gizi dalam menunjang performa atlet antara lain melakukan pengukuran antropometri dan komposisi tubuh, mengevaluasi pemeriksaan performa secara laboratorium berkaitan dengan status gizi, memberikan edukasi gizi, menyusun strategi intervensi gizi, melakukan penyelenggaraan makan, hingga melaksanakan penelitian di bidang gizi dan olahraga (Thomas et al., 2016; Andersen et al., 2018).

\section{Peraturan Menteri Pemuda dan Olahraga No. 2 Tahun 2017 tentang Tata Cara Pengembangan Ilmu Pengetahuan dan Teknologi Keolahragaan (Kementerian Pemuda dan Olahraga RI, 2017a)}

Pada Pasal 4 ini dijelaskan bidang-bidang keilmuan yang termasuk dalam ilmu dasar dan ilmu terapan dalam rangka riset dan pengembangan IPTEK. Lebih lanjut pada ayat 2 dijelaskan tujuh bidang ilmu untuk pengembangan ilmu dasar (basic science). Pada ayat 3 disebutkan bahwa gizi olahraga (sport nutrition) termasuk satu dari sepuluh bidang ilmu terapan (applied science). Dengan demikian, penerapan ilmu gizi olahraga dalam bentuk pendampingan gizi yang komprehensif sebagai bentuk pengembangan IPTEK Keolahragaan. Hal ini dapat dituangkan dalam Buku Pedoman Penyelenggaraan Gizi Atlet (PPGA).

Perlu diidentifikasi bagaimana peran masing-masing cabang keilmuan tersebut dalam satu sistem pembinaan atlet jangka panjang. Lebih lanjut, aplikasi keilmuan tersebut harus saling melengkapi satu sama lain, melibatkan kolaborasi berbagai tenaga profesi, dengan satu tujuan untuk meningkatkan performa olahraga atlet. Oleh karena itu setiap bidang ilmu yang disebutkan pada Pasal ini dapat dijadikan landasan untuk penyusunan program pembinaan atlet.

Dalam upaya penerapan kolaborasi antar tenaga keolahragaan, Indonesia dapat belajar dari sistem keolahragaan yang lebih terintegrasi di negara lain. Di Australia misalnya, sistem pembinaan atlet oleh Australian Institute of Sports (AIS) menerapkan kolaborasi lintas sektor dengan melibatkan berbagai ahli di bidang ilmu kedokteran olahraga, kekuatan dan pengkondisian (strength \& conditioning), fisiologi, gizi, psikologi, biomekanik, hingga data analis di bidang olahraga (Sport Australia, 2018). Contoh kolaborasi berbagai cabang ilmu keolahragaan lainnya adalah dari Kanada, yang memiliki tim olahraga integrasi (integrated sport team) dalam sistem pembinaan atlet. Dalam tim 


\section{Jurnal Keolahragaan 9 (2), 2021 - 187}

Mirza Hapsari Sakti Titis Penggalih, Laksono Trisnantoro, Zaenal Muttaqqien Sofro, Mutiara Tirta Prabandari

Lintang Kusuma, Mustika Cahya Nirmala Dewinta, Ibtidau Niamilah, Meta Anastasia, Edi Nurinda Susila

tersebut, ahli gizi tergabung sebagai salah satu profesi yang bertujuan dalam mendukung performa olahraga atlet (Erdman, 2015).

\section{Peraturan Presiden No. 95 Tahun 2017 tentang Peningkatan Prestasi Olahraga Nasional (Pemerintah Republik Indonesia, 2017)}

Konsep pembinaan dilakukan "berjenjang dengan prinsip jangka panjang" belum dijabarkan secara jelas, misal jenjang pembinaan atlet junior, senior, elit, atau jenjang pembinaan atlet berdasarkan kelompok usia. Meskipun pada praktiknya pembinaan atlet di Indonesia telah dilakukan secara berjenjang mulai dari pembudayaan olahraga pada masyarakat, pembinaan atlet pelajar, hingga pembinaan atlet pilihan untuk meningkatkan prestasi di level internasional. Saat ini pelaksanaan program pengembangan bakat atlet hanya dibebankan pada induk cabor dan NPC, dengan pengawasan Menteri dibantu KONI. Untuk atlet usia dini pembinaannya sudah menjadi tanggung jawab langsung Kemenpora melalui PPLP dan SKO.

Supaya konsep pembinaan jangka panjang dapat diaplikasikan dengan lebih baik, Kemenpora RI dapat mengadopsi kerangka Long Term Athlete Development (LTAD) yang dirancang oleh Canadian Sport Centers LTAD Experts Group. Kerangka tersebut mendesain strategi pembinaan atlet berdasarkan prinsip fisiologi dari pertumbuhan, perkembangan, dan akuisisi keterampilan olahraga. Secara umum kerangka LTAD membagi tahapan pembinaan atlet menurut usia, yaitu 1) Permulaan usia 0-6 tahun, b) dasar usia 6-9 tahun, c) belajar untuk berlatih usia 8-12 tahun, d) berlatih untuk berlatih usia 11-16 tahun, e) berlatih untuk berkompetisi usia 15-23 tahun, f) berlatih untuk menang usia 18 tahun ke atas, g) aktif sebagai bagian dari hidup bagi atlet dan populasi umum usia 12 tahun ke atas. Berdasarkan kerangka LTAD, pentingnya pemenuhan gizi sebagai penunjang performa olahraga perlu harus mulai diperkenalkan sejak tahap Learn to Train. Ahli gizi pun perlu tergabung dalam tim penunjang performa (Performance Enhancement Team) bersama tenaga keolahragaan lainnya (Balyi et al, 2013; Beaudoin et al, 2015). Kerangka LTAD tersebut perlu diadaptasi dalam buku Pedoman Pembinaan Atlet PPLP/SKO yang dikeluarkan oleh Kemenpora RI dan disosialisasikan ke setiap PPLP/SKO serta stakeholder lain yang terlibat dalam program pembinaan atlet di Indonesia.

Ilmu pengetahuan dan teknologi keolahragaan khususnya di bidang gizi olahraga perlu dijadikan landasan dalam penyusunan program pengembangan bakat calon atlet berprestasi, termasuk pada tahap seleksi atlet. Tata cara pengembangan bakat calon atlet berprestasi tercantum dalam Permenpora No 24 Tahun 2017, namun pengertian istilah Pelatihan Performa Tinggi tidak didefinisikan dengan jelas. Pelatihan performa tinggi (high-performance training) adalah program latihan intensif yang ditujukan untuk mengasah keterampilan dan mengoptimalkan performa olahraga atlet sebelum mengikuti pertandingan olahraga berlevel tinggi (Ardiyanto, 2019).

Apabila mengacu pada Ketentuan Umum di Bab I (Pasal 2) pelatihan nasional diikuti oleh atlet berprestasi yang terseleksi oleh induk cabang olahraga, maka dapat diartikan bahwa Pelatihan performa tinggi pada pasal 12 ini adalah program latihan di pelatihan nasional tersebut. Dengan demikian, diperlukan penjelasan yang jelas terhadap prinsip pelatihan performa tinggi, seperti progressive training, adaptation and specification, and individualize program.

Pada dasarnya terdapat 7 prinsip latihan pada atlet untuk meningkatkan performa olahraga, yaitu: progressive (peningkatan beban latihan secara berkala), overload, (peningkatan beban latihan di atas standar latihan normal), adaptation (merancang kemampuan adaptasi tubuh terhadap beban latihan yang ditingkatkan secara bertahap), recovery (fase istirahat atau pemulihan di antara sesi latihan satu dan lainnya), specificit, (peningkatan keterampilan spesifik sesuai cabang olahraga), reversibilit (pelaksanaan program latihan secara teratur dan terus menerus), individualit (penyesuaian program latihan untuk setiap individu atlet).

Seluruh prinsip-prinsip tersebut saling berkaitan, sehingga perlu diterapkan untuk mencapai kesuksesan program latihan. Pada dasarnya, program kekuatan dan pengkondisian (strength and conditioning) adalah rangkaian program latihan yang bertujuan untuk membentuk komposisi tubuh terbaik dan membangun kekuatan fisik yang optimal, sehingga kondisi fisik atlet siap untuk diberi pembebanan latihan yang lebih tinggi dan spesifik sesuai cabang olahraganya. Selama fase latihan kekuatan dan pengkondisian ini, program latihan perlu pemenuhan gizi yang tepat agar terbentuk komposisi tubuh yang ideal, terjadi peningkatan massa dan kekuatan otot, sehingga kondisi fisik siap untuk diberikan program latihan yang lebih lanjut (advanced). Dengan demikian, keterlibatan ahli gizi 


\section{Jurnal Keolahragaan 9 (2), 2021 - 188}

Mirza Hapsari Sakti Titis Penggalih, Laksono Trisnantoro, Zaenal Muttaqqien Sofro, Mutiara Tirta Prabandari

Lintang Kusuma, Mustika Cahya Nirmala Dewinta, Ibtidau Niamilah, Meta Anastasia, Edi Nurinda Susila

dalam menunjang pemenuhan gizi atlet sangat diperlukan pada fase latihan kekuatan dan pengkondisian ini (Lloyd et al., 2019).

Program latihan strength and conditioning membutuhkan jangka waktu yang panjang serta dimulai sejak pembinaan atlet usia dini. Dalam konteks Peningkatan Prestasi Olahraga Nasional, program strength and conditioning semestinya diterapkan mulai dari Pengembangan Bakat Calon Atlet Berprestasi, melalui pembinaan atlet di PPLP, SKO, dan klub olahraga tingkat pelajar lainnya. Pernyataan ayat (2) bahwa penerapan IPTEK diberikan melalui pendidikan dan pelatihan kepada atlet dan pelatih, mengindikasikan bahwa penerapan IPTEK hanya dilakukan dalam bentuk edukasi, bukan dalam bentuk kebijakan/rancangan program. Seperti yang telah menjadi pertimbangan pertama dalam Perpres No. 95 Tahun 2017 ini, untuk mendapatkan atlet yang berprestasi memerlukan pembinaan dan pelatihan secara sistematis, terencana, berkesinambungan, dan modern. Artinya, IPTEK Keolahragaan harus dijadikan salah satu landasan dalam penyusunan kebijakan program pembinaan atlet, tidak hanya sebagai materi edukasi.

Standar minimal pelatihan performa tinggi yang melibatkan ahli gizi perlu direncanakan oleh setiap Induk Organisasi Cabang Olahraga dan NPC agar capaian program pelatihan performa dapat efektif. Standar minimal kebutuhan tim pendukung yang harus dilibatkan dalam sebuah tim olahraga juga perlu disusun. Kesuksesan peningkatan prestasi olahraga nasional membutuhkan kerjasama dengan berbagai profesi yang mendukung pencapaian performa olahraga optimal. Selain atlet dan pelatih, dibutuhkan keterlibatan tim pendukung, meliputi dokter, psikolog, ahli gizi, ahli biomekanik, fisioterapis, masseaur, dan tenaga pendukung lainnya.

\section{Peraturan Menteri Pemuda dan Olahraga No. 24 Tahun 2017 tentang Kriteria dan Standar Pengembangan Bakat Calon Atlet Berprestasi Serta Pemberian Penghasilan dan Fasilitas Kepada Atlet dan Pelatih Atlet Berprestasi (Kementerian Pemuda dan Olahraga RI, 2017b)}

Pasal 4 menyebutkan 3 kriteria yang diperhatikan dalam Pengembangan bakat calon atlet berprestasi, yaitu konten, manajemen, dan dukungan. Pasal 5 menyebutkan 4 kriteria yang diperhatikan dari aspek konten dalam program pengembangan bakat tersebut. Namun belum ada penjelasan lebih lanjut tentang standar minimal dari setiap kriteria tersebut. Standar adalah ukuran yang digunakan untuk menentukan apakah sesuatu memenuhi persyaratan atau kriteria yang ditentukan. Tanpa adanya ukuran atau standar minimal yang jelas, maka sistem monitoring dan evaluasi terhadap implementasi program pengembangan bakat atlet menjadi kurang terukur.

Perlu penjelasan lebih lanjut tentang berbagai bentuk pembinaan atlet di Indonesia, termasuk pihak yang bertanggungjawab dalam pengelolaannya. Pada praktiknya, di Indonesia terdapat berbagai bentuk pembinaan atlet mulai dari SKO, Kelas Khusus Olahraga (KKO), PPLP, Pusat Pendidikan dan Latihan Mahasiswa (PPLM), hingga sekolah olahraga spesifik cabang olahraga tertentu yang dikelola oleh swasta.

Penjelasan tersebut berfungsi untuk mengidentifikasi berbagai stakeholder yang terlibat dalam pembinaan atlet di setiap jenjang pembinaan, sehingga dapat disusun kerangka koordinasi antar stakeholder dalam sistem pembinaan atlet jangka panjang. Dibutuhkan pula standarisasi program pengembangan bakat atlet pada setiap jalur pembinaan seperti yang tercantum pada Pasal 11. Pembinaan kehidupan sosial dalam Pasal 16 dan 17 ini hanya berlaku selama program pelatihan nasional menjelang kompetisi olahraga level internasional, sementara pembinaan kehidupan sosial atlet pada jenjang pengembangan bakat belum diatur. Mengacu pada Pasal 17 ayat (1), atlet berhak memperoleh konsumsi, makanan tambahan olahragawan (suplemen), dan layanan pemeriksaan kesehatan. Artinya, pendampingan gizi oleh ahli gizi sangat dibutuhkan dalam hal penyelenggaraan food service, penyediaan sport food, dan pemeriksaan status gizi yang menjadi bagian dari health-related fitness.

Terkait Pasal 17 ayat (3), diperlukan ketentuan lebih lanjut mengenai standar layanan minimal pada pemeriksaan kesehatan yang difasilitasi oleh RSON dan PPITKON, seperti frekuensi minimal pemeriksaan kesehatan, bentuk pemeriksaan kesehatan, evaluasi keberhasilan pembinaan atlet menggunakan hasil pemeriksaan selama periode pelatihan nasional, termasuk perbaikan yang diperlukan.

Pasal 20 poin 'd' menyebutkan bahwa dalam rangka peningkatan prestasi olahraga nasional, dilaksanakan pelatihan performa tinggi dengan menerapkan IPTEK Keolahragaan. Mengacu pada Permenpora No 2 Tahun, Pasal 4 Ayat (3), gizi olahraga (sport nutrition) merupakan salah satu cabang 


\section{Jurnal Keolahragaan 9 (2), 2021 - 189}

Mirza Hapsari Sakti Titis Penggalih, Laksono Trisnantoro, Zaenal Muttaqqien Sofro, Mutiara Tirta Prabandari

Lintang Kusuma, Mustika Cahya Nirmala Dewinta, Ibtidau Niamilah, Meta Anastasia, Edi Nurinda Susila

ilmu terapan (applied science) yang perlu diterapkan untuk meningkatkan kualitas pembinaan dan pengembangan olahraga. Pasal 20 poin 'h' menyebutkan bahwa ahli gizi merupakan salah satu tim pendukung yang dilibatkan dalam penyelenggaraan kegiatan peningkatan prestasi olahraga nasional.

\section{Peraturan Menteri Pemuda dan Olahraga No. 5 Tahun 2020 tentang Pelimpahan Sebagian Urusan Pemerintahan Bidang Kepemudaan dan Keolahragaan Kepada Gubernur Sebagai Wakil Pemerintah Pusat Dalam Rangka Penyelenggaraan Dekonsentrasi (Kementerian Pemuda dan Olahraga RI, 2020)}

Peningkatan tenaga dan organisasi keolahragaan termasuk dalam ruang lingkup kegiatan dan pengelolaan dana dekonsentrasi. Dalam konteks usulan kebijakan ini dapat direkomendasikan adanya alokasi anggaran dana dekonsentrasi untuk penempatan ahli gizi sebagai tenaga keolahragaan di PPLP/SKO.

\section{Rekomendasi Kebijakan}

Dari uraian dasar hukum yang telah disebutkan, diperoleh rumusan bahwa gizi merupakan bagian dari ilmu pengetahuan dan teknologi keolahragaan yang harus dikembangkan dalam rangka pembentukan dan pembinaan atlet berprestasi. Bersamaan dengan rumusan tersebut, disebutkan pula bahwa ahli gizi merupakan tenaga keolahragaan yang dapat melakukan praktik penyelenggaraan makanan secara berkelompok baik pada individu sakit maupun sehat. Disebutkan bahwa, gizi merupakan bagian dari pengembangan IPTEK yang dibutuhkan tidak hanya untuk melakukan penyelenggaraan makanan, namun juga untuk menyelenggarakan latihan performa tinggi.

Praktik tersebut dapat dilakukan di beberapa lokasi seperti SKO dan PPLP. Hal ini didukung oleh kebijakan yang menyebutkan bahwa pengembangan bakat calon atlet berprestasi dapat dimulai pada kelompok usia junior, pra-remaja, dan remaja. Proses pendampingan membutuhkan waktu yang berjenjang dan berkelanjutan karena gizi merupakan bentuk pendampingan yang bersifat individual dan holistik pada masing-masing atlet. Koordinasi yang baik dengan berbagai pihak terkait dibutuhkan untuk menghasilkan performa atlet yang sehat dan berprestasi.

Keberhasilan atlet-atlet suatu bangsa menorehkan prestasi tingkat internasional akan meningkatkan martabat bangsa tersebut. Tujuan inilah yang dituangkan Kemenpora RI dalam sasaran jangka panjang program-programnya, yaitu mengantarkan atlet-atlet Indonesia untuk berprestasi di kompetisi olahraga internasional. Pembentukan atlet berprestasi ini dapat diperoleh dari pembinaan yang dilakukan sejak dini. Di Indonesia, atlet-atlet muda dibina dalam program pembinaan atlet bernama PPLP dam SKO. Program kerja pembinaan atlet muda di PPLP dan SKO selama ini direncanakan dan disusun Kemenpora RI sejalan dengan desain besar program dari Bappenas dan Kementerian Keuangan.

Keberhasilan di semua program kerja ini melibatkan interaksi kompleks antara beberapa stakeholder atau pemangku kepentingan internal dan eksternal sesuai dengan peran masing-masing. Stakeholder internal yaitu pemangku kepentingan di dalam organisasi Kemenpora yang meliputi Deputi 3, yaitu Asisten Deputi Kemitraan dan Penghargaan, serta Asisten Deputi Sentra dan SKO. Sedangkan stakeholder eksternal yaitu pemangku kepentingan di luar organisasi Kemenpora, yang meliputi: Bappenas, Kementerian Keuangan, Pemerintah Daerah Provinsi, Rumah Sakit dan Dinas Kesehatan setempat, Perguruan Tinggi, Badan Usaha Milik Negara (BUMN), TNI-Polri, organisasi profesi, Komite Olahraga Nasional Indonesia (KONI) daerah dan perusahaan setempat yang dapat dilibatkan dalam sponsorship pengadaan alat-alat olahraga.

\section{SIMPULAN}

\section{Kesimpulan}

Urgensi peran ahli gizi dalam pembinaan atlet telah didukung oleh perundangan serta peraturan pendukungnya. Namun, masih perlu kebijakan operasional yang mengatur tentang penempatan ahli gizi sebagai tenaga keolahragaan, meliputi tugas, wewenang, standar kompetensi, dan sertifikasi ahli gizi sebagai tenaga keolahragaan. 


\section{Jurnal Keolahragaan 9 (2), 2021 - 190}

Mirza Hapsari Sakti Titis Penggalih, Laksono Trisnantoro, Zaenal Muttaqqien Sofro, Mutiara Tirta Prabandari

Lintang Kusuma, Mustika Cahya Nirmala Dewinta, Ibtidau Niamilah, Meta Anastasia, Edi Nurinda Susila

\section{Saran}

Adapun seluruh rangkuman kebijakan dan stakeholder yang diharapkan terlibat dalam implementasi kebijakan ini dapat dirumuskan sesuai pada Tabel 2.

Tabel 2. Rekomendasi Kebijakan dan Stakeholder Terkait

\begin{tabular}{|c|c|c|c|}
\hline No. & Rekomendasi Kebijakan & Pemangku Kebijakan Terkait & Output \\
\hline 1. & $\begin{array}{l}\text { Menerbitkan Kebijakan operasional } \\
\text { tentang penempatan ahli gizi di pusat } \\
\text { pelatihan atlet, baik berupa Peraturan } \\
\text { Menteri, Surat Edaran Menteri, } \\
\text { Peraturan Daerah dan sejenisnya. }\end{array}$ & $\begin{array}{l}\text { Kemenpora, Kemenpan RB, } \\
\text { Bappenas, Kemenkes, } \\
\text { Kemenko PMK }\end{array}$ & $\begin{array}{l}\text { Peraturan Menteri, Surat } \\
\text { Edaran Menteri dan Peraturan } \\
\text { Daerah. }\end{array}$ \\
\hline 2. & $\begin{array}{l}\text { Menerbitkan dan mendiseminasikan } \\
\text { bagan koordinasi dan tata kelola antar } \\
\text { tenaga keolahragaan yang terlibat } \\
\text { dalam sistem pembinaan atlet. }\end{array}$ & $\begin{array}{l}\text { Kemenpora (Asdep } \\
\text { Peningkatan Tenaga dan } \\
\text { Organisasi keolahragaan) }\end{array}$ & $\begin{array}{l}\text { Kegiatan deseminasi berupa } \\
\text { Webinar/Lokakarya }\end{array}$ \\
\hline 3. & $\begin{array}{l}\text { Pelaksanaan uji coba penempatan ahli } \\
\text { gizi. }\end{array}$ & $\begin{array}{l}\text { Kemenpora dan } \\
\text { Perguruan Tinggi }\end{array}$ & $\begin{array}{l}\text { MoU Kemenpora dengan } \\
\text { Perguruan Tinggi }\end{array}$ \\
\hline 4. & $\begin{array}{l}\text { Merumuskan, melakukan, } \\
\text { mengevaluasi dan menetapkan } \\
\text { standarisasi kompetensi, standarisasi } \\
\text { pelatihan dan standarisasi } \\
\text { pendampingan gizi atlet bersama } \\
\text { perguruan tinggi penyelenggara } \\
\text { pendidikan gizi oleh badan } \\
\text { standardisasi. }\end{array}$ & $\begin{array}{l}\text { Kemenpora, } \quad \text { Kemenkes, } \\
\text { PERSAGI, KTKI \& } \text { MTKI, } \\
\text { AIPGI, AIPVOGI, badan } \\
\text { standardisasi }\end{array}$ & $\begin{array}{ll}\text { a. Standar Kompetensi Ahli } \\
\text { Gizi Olahraga } \\
\text { (Steinmuller et al., 2014) } \\
\text { b. Standar Program } \\
\text { Pelatihan Ahli Gizi } \\
\text { Olahraga. } \\
\text { c. Standar Pendampingan } \\
\text { Gizi Atlet. }\end{array}$ \\
\hline
\end{tabular}

\section{DAFTAR PUSTAKA}

Ardiyanto, H. (2019). Pembibitan Bakat Olahraga: Suatu Eksplorasi Konsep. Proceedings National Seminar of Sport Science, (November), 231-240.

Baihaqi, A. B., Puspitasari, M., Zuraida, M., \& Nurcholis, A. (2021). Perencanaan manajemen risiko atlet berprestasi Indonesia (Studi kasus atlet dengan risiko cedera tinggi). Jurnal Keolahragaan, 9(1), 137-147. https://doi.org/10.21831/jk.v9i1.33856

Balyi, I., Way, R., \& Higgs, C. (2013). Long-Term Athlete Development. Retrieved from https://books.google.com.hk/books?hl=zh-

TW\&lr=\&id=ovJ6DwAAQBAJ\&oi=fnd\&pg=PT10\&dq=long+term+athlete+development+mod el+in+track+and+field\&ots=dB7yLaXRXR\&sig=d8j17KzU9nyJwxWVmSWOGIIKTvk\&redir esc $=\mathrm{y} \# \mathrm{v}=$ onepage $\& \mathrm{q}=$ long term athlete development model in track and

Beaudoin, C., Callary, B., \& Trudeau, F. (2015). Coaches' Adoption and Implementation of Sport Canada's Long-Term Athlete Development Model. SAGE Open, 5(3). https://doi.org/10.1177/2158244015595269

Berg, E. K. (2019). Performance Nutrition for the Adolescent Athlete: A Realistic Approach. Clinical Journal of Sport Medicine, 29(5), 345-352. https://doi.org/10.1097/JSM.0000000000000744

Blomkamp, E., Sholikin, M. N., Nursyamsi, F., Lewis, J. M., \& Toumbourou, T. (2017). Understanding Policymaking in Indonesia: In Search of a Policy Cycle. In KSI Working Paper. Retrieved from https://www.ksi-indonesia.org/en/news/detail/understanding-policy-making-inindonesia-in-search-of-a-policy-cycle

Bytomski, J. R. (2018). Fueling for Performance. Sports Health, 10(1), 47-53. https://doi.org/10.1177/1941738117743913

Erdman, K. A. (2015). A lifetime pursuit of a sports nutrition practice. Canadian Journal of Dietetic Practice and Research, 76(3), 150-154. https://doi.org/10.3148/cjdpr-2015-021 


\section{Jurnal Keolahragaan 9 (2), 2021 - 191}

Mirza Hapsari Sakti Titis Penggalih, Laksono Trisnantoro, Zaenal Muttaqqien Sofro, Mutiara Tirta Prabandari

Lintang Kusuma, Mustika Cahya Nirmala Dewinta, Ibtidau Niamilah, Meta Anastasia, Edi Nurinda Susila

Health Policy Project. (2014). Capacity Development Resource Guide: Implementation Barriers. Retrieved from

https://www.healthpolicyproject.com/pubs/272_ImplementationBarriersResourceGuide.pdf

Jenner, S. L., Trakman, G., Coutts, A., Kempton, T., Ryan, S., Forsyth, A., \& Belski, R. (2018). Dietary intake of professional Australian football athletes surrounding body composition assessment. Journal of the International Society of Sports Nutrition, 15(1), 1-8. https://doi.org/10.1186/s12970-018-0248-5

Jones, G. R. (2013). Organizational Theory, Design , and Change. In Pearson Education Limited. Upper Saddle River: Pearson.

Kementerian kesehatan RI. Peraturan Menteri Kesehatan Republik Indonesia Nomor 26 tahun 2013 Tentang Penyelenggaraan Pekerjaan dan Praktik Tenaga Gizi. , (2013).

Kementerian Pemuda dan Olahraga RI. Peraturan Menteri Pemuda dan Olahraga Republik Indonesia Nomor 1684 Tahun 2015 Tentang Persyaratan Pemberian Penghargaan Olahraga kepada Olahragawan, Pembina Olahraga, Tenaga Keolahragaan, dan Organisasi Olahraga. , (2015).

Kementerian Pemuda dan Olahraga RI. Peraturan Menteri Pemuda dan Olahraga Republik Indonesia Nomor 2 Tahun 2017 Tentang Tata Cara Pengembangan Ilmu Pengetahuan dan Teknologi Keolahragaan., (2017).

Kementerian Pemuda dan Olahraga RI. Peraturan Menteri Pemuda dan Olahraga Republik Indonesia Nomor 24 Tahun 2017 Tentang Kriteria dan Standar Pengembangan Bakat Calon Atlet Berprestasi serta Pemberian Penghasilan dan Fasilitasi kepada Atlet dan Pelatih Atlet Berprestasi. , (2017).

Kementerian Pemuda dan Olahraga RI. Peraturan Menteri Pemuda dan Olahraga Republik Indonesia Nomor 5 Tahun 2020 tentang Pelimpahan Sebagian Urusan Pemerintahan Bidang Kepemudaan dan Keolahragaan kepada Gubernur Sebagai Wakil Pemerintah Pusat dalam Rangka Penyelenggaraan Dekonsentrasi., (2020).

Kim, S. H., Oh, C. S., \& Lee, J. H. (2019). Dietary nutrient intake of Korean adolescent distance runners. Journal of Exercise Rehabilitation, 15(6), 781-786. https://doi.org/10.12965/jer.1938682.341

Lloyd, R. S., Radnor, J. M., Moeskops, S., Meyers, R. W., Read, P. J., \& Oliver, J. L. (2019). Applying Strength and Conditioning Practices to Young Athletes. Routledge Handbook of Strength and Conditioning, 23-37. https://doi.org/10.4324/9781315542393-3

Ong, J. L., \& Brownlee, I. A. (2017). Energy Expenditure, Availability, and Dietary Intake Assessment in Competitive Female Dragon Boat Athletes. Sports, 5(4), 45. https://doi.org/10.3390/sports5020045

Pemerintah Republik Indonesia. Undang-Undang Republik Indonesia Nomor 3 Tahun 2005 Tentang Sistem Keolahragaan Nasional. , (2005).

Pemerintah Republik Indonesia. Peraturan Pemerintah Republik Indonesia Nomor 16 Tahun 2007 Tentang Penyelenggaraan Keolahragaan., (2007).

Pemerintah Republik Indonesia. Peraturan Presiden Republik Indonesia Nomor 95 Tahun 2017 Tentang Peningkatan Prestasi Olahraga Nasional., (2017).

Penggalih, M. H. S. T., Dewinta, M. C. N., Solichah, K. M., Pratiwi, D., Niamilah, I., Nadia, A., \& Kusumawati, M. D. (2019). Identifikasi status gizi, somatotipe, asupan makan dan cairan pada atlet atletik remaja di Indonesia. Journal of Community Empowerment for Health, 1(2), 85. https://doi.org/10.22146/jcoemph.38410

Penggalih, M. H. S. T., Juffrie, M., Sudargo, T., \& Sofro, Z. M. (2017). Correlation between nutritional status and lifestyle for youth soccer athlete performance: A cohort study. Pakistan Journal of Nutrition, 16(12), 895-905. https://doi.org/10.3923/pjn.2017.895.905 


\section{Jurnal Keolahragaan 9 (2), 2021 - 192}

Mirza Hapsari Sakti Titis Penggalih, Laksono Trisnantoro, Zaenal Muttaqqien Sofro, Mutiara Tirta Prabandari Lintang Kusuma, Mustika Cahya Nirmala Dewinta, Ibtidau Niamilah, Meta Anastasia, Edi Nurinda Susila

Penggalih, M. H. S. T., Narruti, N. H., Fitria, F., Pratiwi, D., Sari, M. D. P., Winata, I. N., ... Kusumawati, M. D. (2016). Identification of somatotype, nutritional status, food and fluid intake in gymnastics youth athletes. Asian Journal of Clinical Nutrition, 8(1-3), 1-8. https://doi.org/10.3923/ajen.2016.1.8

Sepriadi, S. (2017). Kontribusi status gizi dan kemampuan motorik terhadap kesegaran jasmani siswa sekolah dasar. Jurnal Keolahragaan, 5(2), 194. https://doi.org/10.21831/jk.v5i2.15147

Sport Australia. (2018). Sport 2030. Canbera: Australian Government.

Steinmuller, P. L., Kruskall, L. J., Karpinski, C. A., Manore, M. M., Macedonio, M. A., \& Meyer, N. L. (2014). Academy of nutrition and dietetics: Revised 2014 standards of practice and standards of professional performance for registered dietitian nutritionists (competent, proficient, and expert) in sports nutrition and dietetics. Journal of the Academy of Nutrition and Dietetics, 114(4), 631-641.e43. https://doi.org/10.1016/j.jand.2013.12.021

Sulistiyono, N. Y. (2020). Kebijakan Pembinaan Olahraga Prestasi Mellaui PPLP Jawa Barat. UNIVERSITAS PENDIDIKAN INDONESIA.

Tahir, A. F., Basith, I., \& Arimbi. (2019). Survei Status Gizi Atlet PPLP Provinsi sulawesi selatan. 19.

Thomas, D. T., Erdman, K. A., \& Burke, L. M. (2016). Position of the Academy of Nutrition and Dietetics, Dietitians of Canada, and the American College of Sports Medicine: Nutrition and Athletic Performance. Journal of the Academy of Nutrition and Dietetics, 116(3), 501-528. https://doi.org/10.1016/j.jand.2015.12.006

von Rosen, P., Frohm, A., Kottorp, A., Fridén, C., \& Heijne, A. (2017). Multiple factors explain injury risk in adolescent elite athletes: Applying a biopsychosocial perspective. Scandinavian Journal of Medicine and Science in Sports, 27(12), 2059-2069. https://doi.org/10.1111/sms.12855 